\title{
AEROSPACE MONITORING OF THE FOREST ECOSYSTEM DYNAMICS WITHIN THE TERRITORY OF VRACHANSKI BALKAN NATURE PARK
}

\author{
Adlin Dancheva
}

\begin{abstract}
In this paper the application of Remote Sensing and GIS as a means of performing aero - space monitoring of forest ecosystems dynamics is being considered. The purpose of this work is to create a model for monitoring the dynamic of forest ecosystems, based on Remote Sensing and GIS. The results of ecomonitoring can be used to update plans and policies for forest ecosystem management. The territory of Vrachanski Balkan Nature park was chosen as the subject of research as there is a certain anthropogenic pressure there. The results presented are obtained by spatial-time analysis of certain aerospace data indices. To carry out the study optical satellite images were used, on the basics of which three indices were calculated: Normalized Difference Vegetation Index (NDVI), Normalized Difference Water Index (NDWI) and Normalized Difference Greenness Index (NDGI). A comparative analysis has been created and results of the degree of correlation between the different indices are presented, as well as indicators from the different test areas and related changes in the individual points in time. The results of the survey aim to assess the dynamics and condition of the forest vegetation on the territory of Vrachanski Balkan Nature park and can be utilised in activities related to monitoring, mapping and forest management.
\end{abstract}

Key words: monitoring, forest ecosystems, remote sensing, NDVI, NDGI, NDWI

\section{INTRODUCTION}

Forest ecosystems have an important social, ecological, and environment-forming role through which they benefit the climate, as well as the hydrological cycle of rivers and protect soil against erosion. Environment monitoring is necessary in order to maintain and control the environment's parameters. It also serves as the basis for studies researching solutions to particular ecological problems from a scientific standpoint. Monitoring has the following functions: observation, discovery, analysis, and modelling. When discussing monitoring of forest vegetation what needs to be taken into account are the forests' ecosystems characteristics in relation to their geographical situation, forest type and particular relief traits. The physiological activity of the forest cover is influenced by durability and life status of the vegetation in question. Physiological processes that mainly affect vegetation growth are photosynthesis and evapotranspiration. The use of satellite data in different spectral ranges allows quantitative ecodynamic evaluation through various indexes $[1,2]$. Aerospace technologies are widely used in carrying out such monitoring which in turn helps plan and manage forest resources while also providing potential for mapping forest types and their distribution range.

\section{STUDY AREA}

This paper deals with studying forest ecosystems within the territory of Vrachanski Balkan Nature
Park. The boundary of this territory is accepted to be the same as the boundary of the national park itself. The park covers an area of 30129.9 ha of which the forest vegetation covers 18575.8 ha. The mean altitude within the park is 700 m.a.s.l. with the highest peak being Beglichka mogila with 1481.7 m.a.s.l. [3]

The goal of this paper is to monitor the forest vegetation's dynamic at 4 points in time by using vegetation indexes obtained through aerospace data.

Fig. 1 represents the situation and range of the territory of Vrachanski Balkan Nature Park. It is located in the Northwest part of Bulgaria with the coordinates $23^{\circ} 23^{\prime} / 23^{\circ} 45^{\prime}$ east longitute и $43^{\circ} 05^{\prime} / 43^{\circ} 17^{\prime}$ north latitude (WGS 84 , UTM $34 \mathrm{~N}$ ).

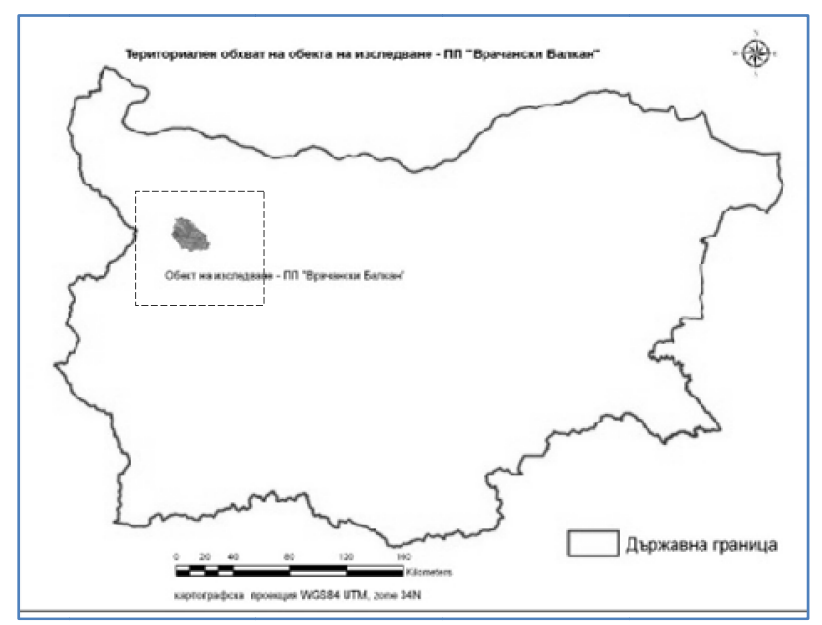

Fig.1. Area of the studied territory - Vrachanski Balkan Nature Park 


\section{MATERIALS AND METHODS}

The monitoring is based on satellite data provided by the multispectral instrument (MSI) of the platform Sentinel 2 of the Copernicus program [4]. The selected images have either no or a low degree of cloud coverage and are from two different years and seasons - summer and autumn. Table 1 provides a list of the images used.

Table 1. Satellite images used

\begin{tabular}{|l|l|}
\hline Date & Satellite \\
\hline 13.07 .2016 & Sentinel 2 MSI \\
\hline 07.08 .2017 & Sentinel 2 MSI \\
\hline 16.09 .2017 & Sentinel 2 MSI \\
\hline 21.10 .2017 & Sentinel 2 MSI \\
\hline
\end{tabular}

This particular sensor was used because of its suitable spectral, spatial, and temporal resolution. The quantitative evaluation of the changes during the different seasons makes use of the following indexes: Normalized Difference Vegetation Index (NDVI), Normalized Difference Water Index (NDWI) and Normalized Difference Greenness Index (NDGI).

The most commonly used indicator of vegetation status and vitality is NDVI [5]. NDVI is an indicator of the potential for absorption and reflection of the input energy from vegetation, it's photosynthetic capacity and the concentration of biomass and is expressed by the following formula:

$$
N D V I=\frac{\rho_{N I R-} \rho_{R E D}}{\rho_{N I R+} \rho_{R E D}}
$$

where $\rho_{\text {NIR }}$ is the reflection of the radiant energy in the near infrared range of the spectrum, and $\rho_{-}$RED is the reflection in the red part in the visible spectrum range.

dNDVI represents the difference of two NDVIs from different time points and is expressed by the following formula:

$$
d N D V I=N D V I\left(t_{2}\right)-N D V I\left(t_{1}\right)
$$

To get the difference, take NDVI for the last date (t2) and deduct from it the one for the earliest date (t1).

For the assessment of the presence of moisture in the foliage a Normalized Differential Water Index NDWI is used [6]:

$$
N D W I=\frac{\rho_{N I R-} \rho_{S W I R_{1}}}{\rho_{N I R+} \rho_{S W I R_{1}}}
$$

where $\rho_{S W I R_{1}}$ is the reflection coefficient of the radiant energy in the shortwave infrared range of the spectrum.
The orthogonalization of satellite images is a very effective method of interpreting, classifying and analyzing phenomena and processes related to the dynamics and change of the main components of the earth's surface: soil, vegetation and water [7]. NDGI is defined as a greenness component and it quantifies positive and negative values during growing processes in vegetation. The following expression is used for NDGI [8]:

$$
\mathrm{NDGI}=\frac{\mathrm{GR}_{\mathrm{n}}\left(\mathrm{t}_{2}\right)-\mathrm{GR}_{\mathrm{n}}\left(\mathrm{t}_{1}\right)}{\left|\mathrm{GR}_{\mathrm{n}}\left(\mathrm{t}_{2}\right)\right|+\left|G \mathrm{R}_{\mathrm{n}}\left(\mathrm{t}_{1}\right)\right|}
$$

where: $G R_{n}\left(t_{1}\right)$ and $G R_{n}\left(t_{2}\right)$ - represent respectively the normalized values of the Greenness components at time points $t_{1}$ и $t_{2}$, and $\left|G R_{n}\left(t_{2}\right)\right|$ и $\left|G R_{n}\left(t_{1}\right)\right|$ represent the absolute values of the same components.

$G R_{n}\left(t_{1}\right)$ and $G R_{n}\left(t_{2}\right)$ are obtained based on the following equation:

$$
G R_{n}(t)=\frac{G R(t)-E\{G R(t)\}}{\operatorname{St.Dev}[G R(t)]}
$$

where $E\{G R(t)\}$ is the mean value of $G R(t)$. In this case, for the normalized values is obtained $E\left\{G R_{n}(t)\right\}=0$ and St.Dev. $\left[E\left\{G R_{n}(t)\right]=1\right.$, which means that the values of $G R_{n}(t)$ are absolutely comparable (standardized), regardless on the sensor and time of satellite image capturing. Furthermore, the error stemming from external factor influences during satellite image capturing is significantly diminished.

The index values vary between -1 and +1 ; values below 0 indicate a negative process in the vegetation change; values above 0 indicate a positive process. The value of -1 indicates complete vegetation degradation while values of +1 indicate new growth.

The factors affecting vegetation growth have been assessed on the basis of climate data for mean air temperature, evapotranspiration, radiation, and rainfall [9].

Spectral reflective characteristics have been established (on the basis of the images used from specific test areas within the territory of the studied forest ecosystems) and applied in evaluating the vegetation changes.

\section{RESULTS AND DISCUSSION}

The data used is from the dates $13 / 07 / 2016$, 07/08/2017, 16/09/2017/ and 21/10/2017 which allows the whole process in the year 2017 to be observed.

Fig. 2 represents NDVI on 13/07/2016 - the values vary between 0.47 and 0.88 which indicates a stable vegetation development during this time of the year. For comparison NDWI has been shown as well (Fig. 3) with values between 0.25 and 0.6. 


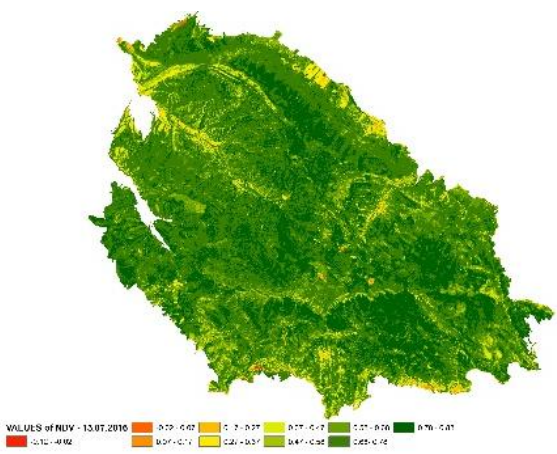

Fig.2. NDVI for 13.07.2016

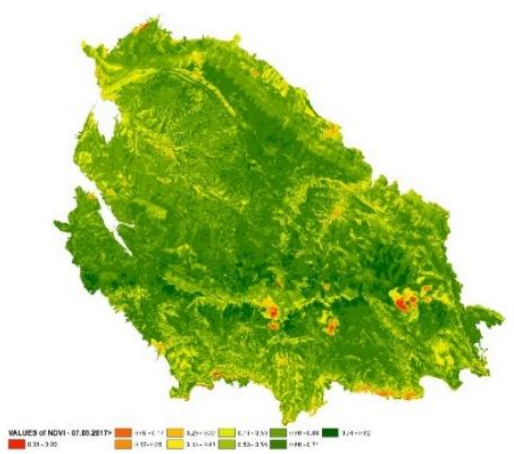

Fig.4. NDVI for 07.08.2017

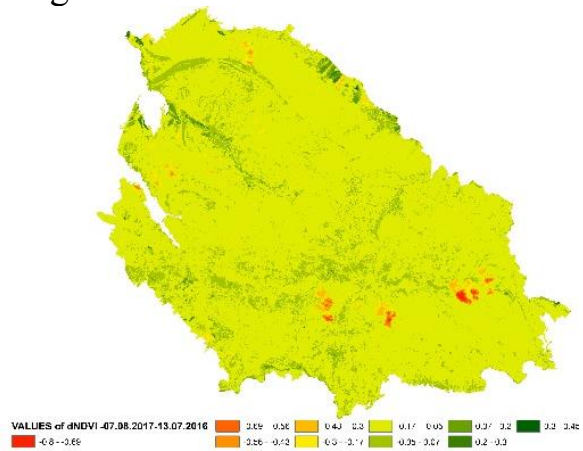

Fig.6. dNDVI for the time period 13.07.2016-07.08.2017 г.

Fig. 4 represents the NDVI values for 07/08/2017 and they show a variation between 0.41 and 0.82 . Similarly, the NDWI values vary as well. Figure 6 and 7 represent the difference in two separate points in time - 13/07/2016 and 07/08/2017.

To corroborate the resulting analyses, a comparison of the climate data base for radiation, rainfall, evapotranspiration, and mean air temperature for a period of 10 days has been carried out. In the second half of July the mean air temperature is $19{ }^{\circ} \mathrm{C}$, rainfall amount $-351 / \mathrm{m}^{2}$,

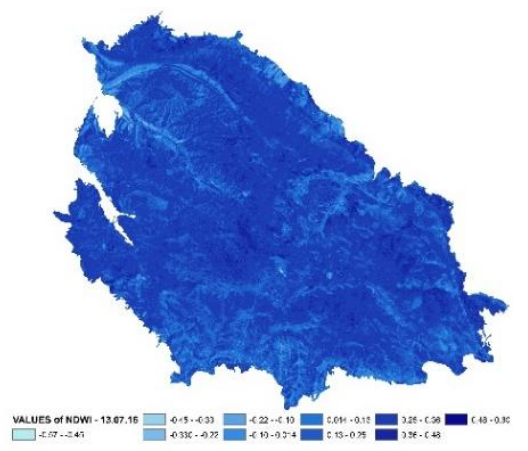

Fig.3. NDWI for 1307.2016

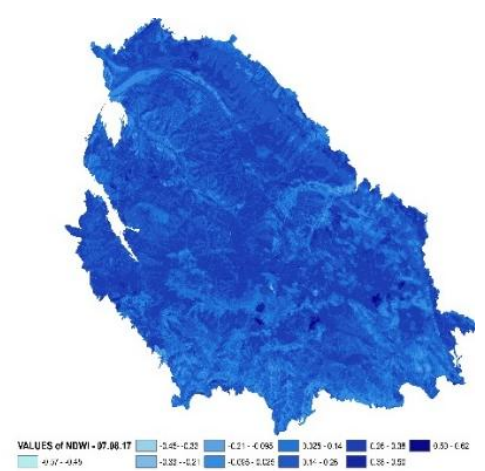

Fig.5. NDWI for 07.08.2017

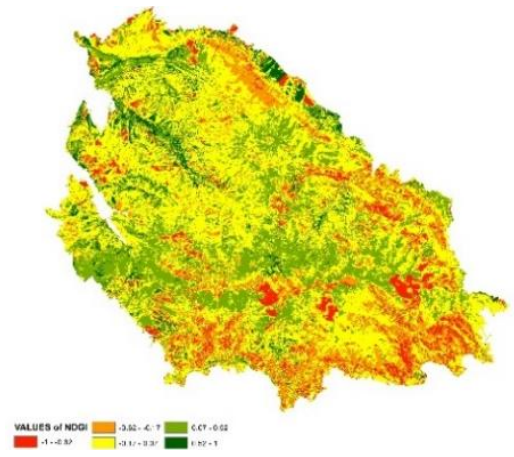

Fig.7. NDGI for the time period 13.07.2016-07.08.2017г.

radiation is high $-22 \mathrm{~kJ} / \mathrm{m}^{2}$ and thus evapotranspiration is higher as well. The higher the radiation, the more intense the evaporation which in turn affects the NDVI values for 07/08/2017. Climate data for August 2017 shows a stark reduction in the amount of rainfall with as low as 1 $1 / \mathrm{m}^{2}$, high evapotranspiration and radiation, and mean air temperature of $25^{\circ} \mathrm{C}$, resulting in die out in the higher tree branches - which is the cause of the index values being lower in comparison to the previous year. 
Fig. 8 represents the NDVI values for $16 / 09 / 2017$ where a decrease in the vegetation index can be observed when compared to the values for 07/08/2017. The reason for this being is a change in climate conditions and a decrease in chlorophyll levels in the leaves. With the decrease in air temperature and evapotranspiration and increase of rainfall plants enter a different phase of development. The climate data presented shows a mean air temperature of $21{ }^{\circ} \mathrm{C}$ with lower evapotranspiration in comparison to July 2016 and August 2017. The mean rainfall quantity for the 10 days in the middle of September is $101 / \mathrm{m}^{2}$ and

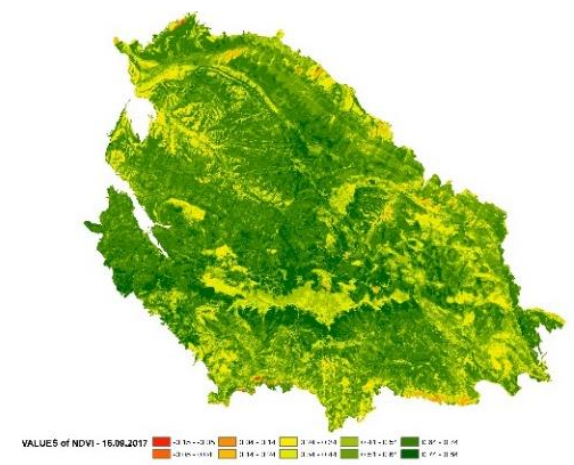

Fig.8. NDVI - 16.09.2017

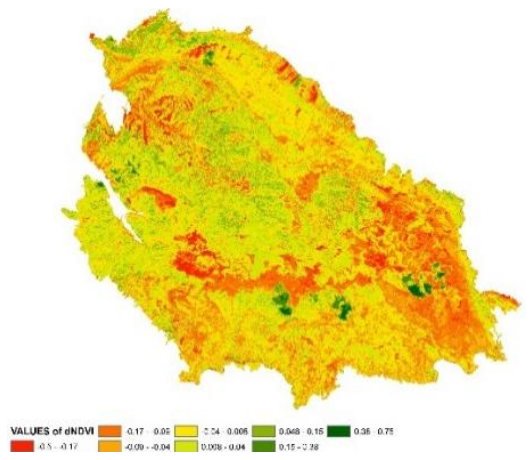

Fig.10. dNDVI - 16.09.2017 - 07.08.2017

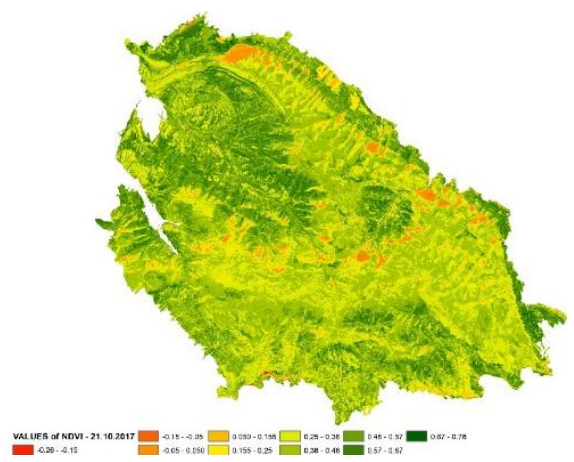

Fig.12. NDVI - 21.10.2017 radiation is lower in comparison to the two previous dates.

Fig. 12 represent the NDVI values for $21 / 20 / 2017$ with a wide variation from between 0.3 to 0.78 owing to changes in the climate conditions. Forest vegetation enters a dormant state when the air temperature drops below $10^{\circ} \mathrm{C}$. In addition, rainfall furthers the lowering of the air temperature. Evapotranspiration and radiation decrease which is a characteristic of the season. On this occasion, one can draw the conclusion that vegetation processes come to a standstill and this is the reason for the lower relative index values.

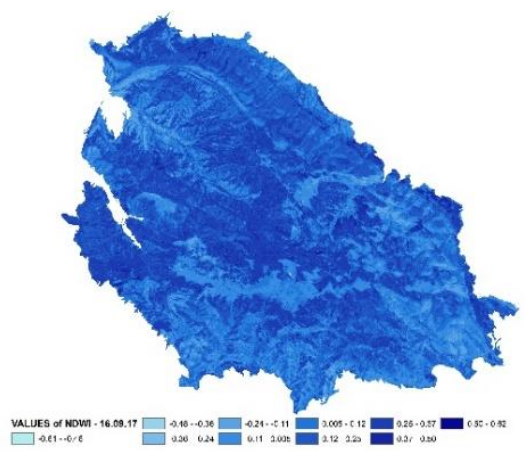

Fig.9. NDWI - 16.09.2017

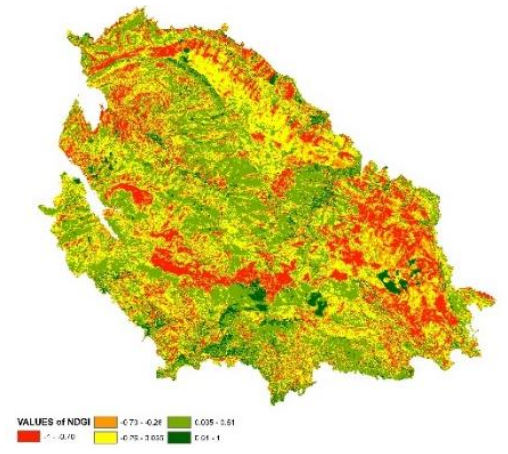

Fig.11. NDGI - 16.09.2017-07.08.2017

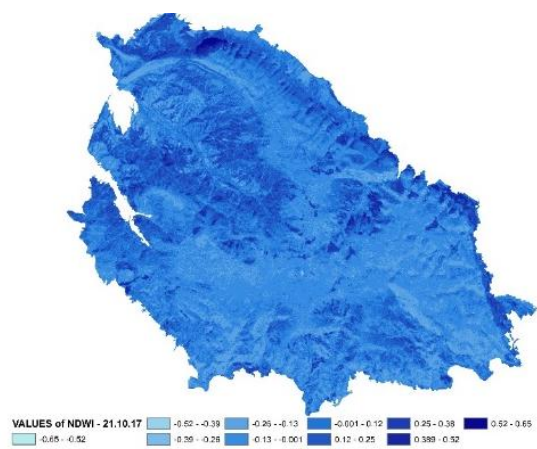

Fig.13. NDWI - 21.10.2017 


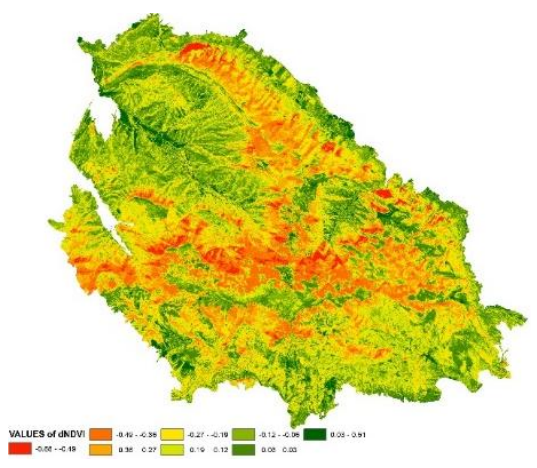

Fig.14. dNDVI - 21.10.2017 - 16.09.2017 Fig.15. NDGI - 21.10.2017 - 16.09.2017

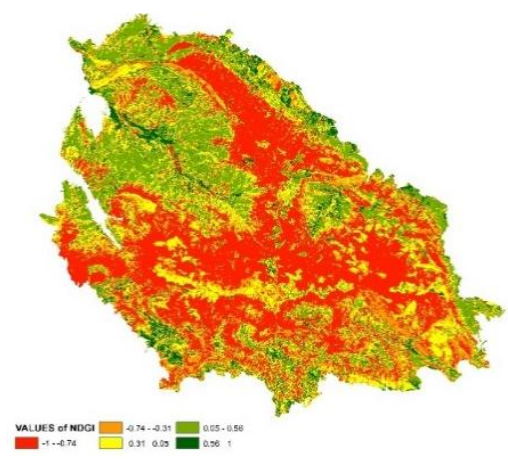

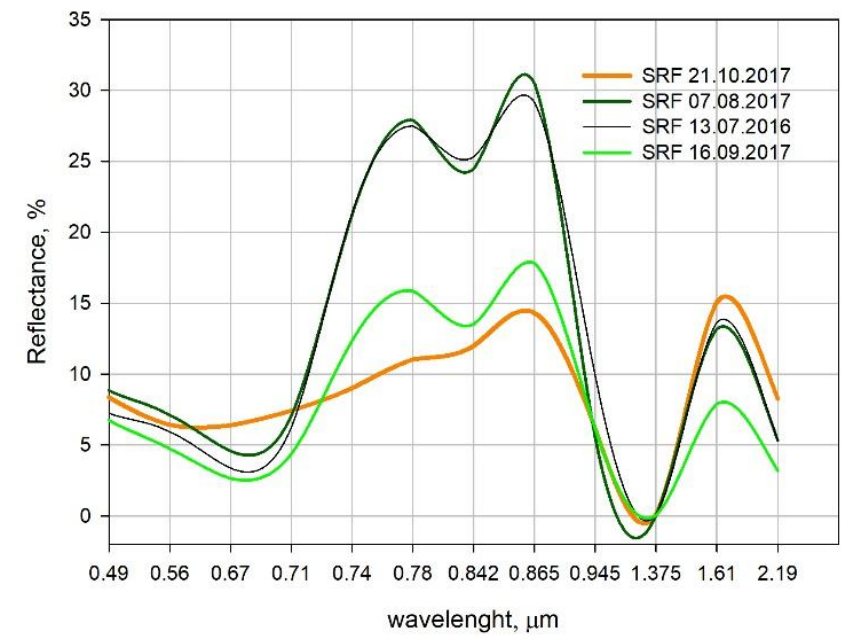

Fig.16. Spectral reflective vegetation characteristic for different dates

Fig. 15 shows a distinct difference between two different time points with the values indicating a high degree of correlation between 16/09/2017 and 21/10/2017.

Fig. 16 shows a reflective vegetation characteristic for the separate points in time and a decrease in reflective values for October 2017 can easily be observed.

Fig. 17 represents the gathered climate data for the studied period with a visible decrease in value from July to October. The highest values for evapotranspiration, radiation and air temperature have been recorded during August 2017 with rainfall decreasing during this period and increasing again in October. Logically, the lowest values for evapotranspiration, radiation and air temperature have been recorded during October 2017.

\section{CONCLUSION}

A comparative analysis of the state of forest ecosystems within the territory of the Vrachanski

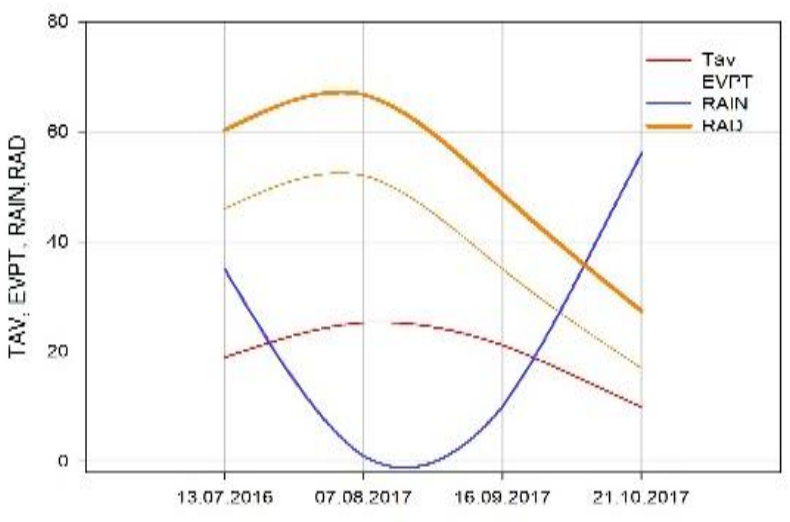

Fig.17. Climate data for the studied period

Balkan National Park in 4 points in time has been carried out. The values of the indexes used reflect the quantitative state of green bio mass in the forest ecosystem. Based on this study the conclusion is that the forest ecosystem development is a stable one. The highest index values are from July 2016 owing to better climate conditions. A significant change can be observed in October when the index values diminish and the vegetation processes in the forest ecosystems come to a stop. For the studied period no negative occurrences have been observed to affect the vegetation.

Acknowledgments: This study was carried out with the support of Project BG161PO003-1.2.04-0053C0001from Operational Programme "Development of the Competitiveness of the Bulgarian Economy 2007-2013" and Programme "COPERNICUS" of European Union (European Space Agency). 


\section{REFERENCES}

1. Tucker C.J., Red and Photographic Infrared Linear Combinations for Monitoring Vegetation. Remote Sensing of Environment, 8, 1979, 127-150. doi: http://dx.doi.org/10.1016/0034-4257(79)90013-0

2. Nedkov R., Pavlova A. Application of the different vegetation indexes regarding to forest physiology and climatic seasons, Scientific Conference "SPACE, ECOLOGY, SAFETY" with International Participation, 10-13 June 2005, Varna, Bulgaria S E S ' 200 5, pp. 263-268

3. http://new.iag.bg/files/lup/101/PPVrachansk iBalkan.pdf

4. https://scihub.copernicus.eu/dhus/\#/home

5. C. J. TUCKER \& P. J. SELLERS (1986) Satellite remote sensing of primary production,
International Journal of Remote Sensing, 7:11, 1395-1416, DOI: 10.1080/01431168608948944

6. Gao B. NDWI - A Normalized Difference Water Index for Remote Sensing of Vegetation Liquid Water from Space; Remote Sens. Environ. 58:257-266 (1996)

7. Nedkov R.. "Normalized Differential Greenness Index for vegetation dynamics assessment", Comptes rendus de l'Acad'emie bulgare des Sciences, 70, 8, Prof.Marin Drinov Publishing House of Bulgarian Academy of Sciences, 2017, ISSN:1310-1331, 1143-1146

8. Nedkov R., (2017): Orthogonal transformation of segmented images from the satellite Sentinel-2, Comptes rendus de l'Académie bulgare des sciences, 70, 5, 687-692

9. http://spirits.jrc.ec.europa.eu/?page id=184

\title{
АЕРОКОСМИЧЕСКИ МОНИТОРИНГ НА ДИНАМИКАТА НА ГОРСКИ ЕКОСИСТЕМИ НА ТЕРИТОРИЯТА НА ПРИРОДЕН ПАРК „ВРАЧАНСКИ БАЛКАН“
}

\author{
Адлин Данчева
}

\begin{abstract}
Резюме: В настоящата работа е разгледан технологичният подход на дистанционните изследвания и ГИС като средство за подпомагане на управлението на горите, отнасящо се до приложения, свързани с мониторинг, картографиране и управление на горите. Представени са резултати, посредством пространствен времеви анализ и вегетационни индекси, получени на базата на аерокосмически данни на територията на ПП „Врачански Балкан“. За основа на направените анализи се използва интерпретацията на спьтникови изображения чрез метода за състоянието на вегетацията - NDVI и метод за оценка на състоянието на влагата в листната маса NDWI. Извършен е сравнителен анализ на базата на оптични сателитни изображения и са представени резултати за степента на корелация между различните индекси и показатели от различните тестови участьци и са изследвани промените в отделните времеви точки. На базата на извършените анализи и получените от тях резултати може да се направи оценка на динамиката и състоянието на горската растителност на територията на ПП „Врачански Балкан“. Получените резултати могат да бъдат използвани за мониторинг на променящите се условия в горите, качествен контрол на процесите, протичащи в тях и съставяне на правилни планове и политика за планиране и управление на горските ресурси.
\end{abstract}

Ключови думи: мониторинг, горски ресурси, аерокосмически данни, NDVI

\section{Adlin Dancheva}

Space Research and Technology Institute at the Bulgarian Academy of Science 1, Acad. G.Bonchev Str.

Sofia 1113, Bulgaria e-mail: adlin.dancheva@space.bas.bg

\author{
Адлин Данчева \\ Институт за космически изследвания \\ и технологии - БАН \\ бул. „Акад. Георги Бончев“, бл 1 \\ София 1113, България \\ e-mail: adlin.dancheva@space.bas.bg
}

